\title{
A Novel ShK-Like Toxic Peptide from the Transcriptome of the Cnidarian Palythoa caribaeorum Displays Neuroprotection and Cardioprotection in Zebrafish
}

\author{
Qiwen Liao ${ }^{1,+}(\mathbb{D})$, Guiyi Gong ${ }^{1,+}$, Shirley Weng In Siu ${ }^{2}{ }^{(0)}$, Clarence Tsun Ting Wong ${ }^{3}$, \\ Huidong $\mathrm{Yu}^{4}$, Yu Chung Tse ${ }^{5}$, Gandhi Rádis-Baptista ${ }^{6, *(1)}$ and Simon Ming-Yuen Lee ${ }^{1, *}$ \\ 1 State Key Laboratory of Quality Research in Chinese Medicine and Institute of Chinese Medical Sciences, \\ University of Macau, Macau, China; liaoqw2007@126.com (Q.L.); yb67530@connect.umac.mo (G.G.) \\ 2 Department of Computer and Information Science, Faculty of Science and Technology, University of Macau, \\ Macau, China; shirleysiu@umac.mo \\ 3 Department of Chemistry, The Chinese University of Hong Kong, Shatin, Hong Kong, China; \\ ClarenceTTW@cuhk.edu.hk \\ 4 Shenzhen Rongxin Biotechnology Co., Ltd., Shenzhen 518054, China; huidong.yu@rongene.com \\ 5 Department of Biology, South University of Science and Technology of China, Shenzhen 518055, China; \\ tseyc@sustc.edu.cn \\ 6 Laboratory of Biochemistry and Biotechnology, Institute for Marine Sciences, Federal University of Ceará, \\ Fortaleza 60165-081, Brazil \\ * Correspondence: gandhi.radis@ufc.br (G.R.-B.); simonlee@umac.mo (S.M.-Y.L.); \\ Tel.: +55-85-3366-7007 (G.R.-B.); +853-8822-4695 (S.M.-Y.L.) \\ + These authors contributed equally to this work.
}

Received: 17 May 2018; Accepted: 8 June 2018; Published: 12 June 2018

Abstract: Palythoa caribaeorum (class Anthozoa) is a zoantharian which, together with other cnidarians, like jellyfishes, hydra, and sea anemones, possesses specialized structures in its tissues, the cnidocytes, which deliver an array of toxins in order to capture prey and deter predators. The whole transcriptome of $P$. caribaeroum was deep sequenced, and a diversity of toxin-related peptide sequences were identified, and some retrieved for functional analysis. In this work, a peptide precursor containing a ShK domain, named PcShK3, was analyzed by means of computational processing, comprising structural phylogenetic analysis, model prediction, and dynamics simulation of peptide-receptor interaction. The combined data indicated that PcShK3 is a distinct peptide which is homologous to a cluster of peptides belonging to the ShK toxin family. In vivo, PcShK3 distributed across the vitelline membrane and accumulated in the yolk sac stripe of zebrafish larvae. Notably, it displayed a significant cardio-protective effect in zebrafish in concentrations inferior to the $\mathrm{IC}_{50}(<43.53 \pm 6.45 \mu \mathrm{M})$, while in high concentrations $\left(>\mathrm{IC}_{50}\right)$, it accumulated in the blood and caused pericardial edema, being cardiotoxic to zebrafish larvae. Remarkably, PcShK3 suppressed the 6-OHDA-induced neurotoxicity on the locomotive behavior of zebrafish. The present results indicated that PcShK3 is a novel member of ShK toxin family, and has the intrinsic ability to induce neuro- and cardio-protective effects or cause cardiac toxicity, according to its effective concentration.

Keywords: zoantharian; ShK-like peptide; dynamics simulation; voltage-gated $\mathrm{K}^{+}$ion channel; calcium-activated $\mathrm{K}^{+}$ion channel; animal toxins

Key Contribution: This study discovered a novel peptide, PcShK3, contains the canonical ShK domain in its structure, from zoantharian, displayed cardio-protective and neuroprotective activity. PcShK3 may expand the number of ShK analogs, and will hopefully provide a valuable variant to serve as a new template to be developed as a therapeutic candidate. 


\section{Introduction}

The phylum Cnidaria comprises some of the most venomous known marine animals. Species in this phylum possess unique stinging cells known as cnidocytes, which deliver potent venomous cocktails that immobilize prey for predation or deter them for self-defense [1]. The cnidarian venoms contain disulfide-rich peptides that are cysteine-stabilized toxins which exert their effects by modifying the properties of the ion channels involved in action potential generation in nerve, heart, and skeletal muscle. Collectively, these peptides are typically 10-60 amino acids long, and folded into well-defined secondary structures that are stabilized by multiple, highly-conserved disulfide bonds, which are validated as inhibitors or modulators of different ion channels and neurotransmitter receptors with high potency and selectivity [2]. Based on the number of amino acid residues and disulfide bonds, these toxins can be grouped into four major structural classes: type 1, having 35 to 37 residues with three disulfide bridges; type 2, having 58 to 59 residues and three disulfide bridges; type 3, having 41 to 42 residues and three disulfide bridges; and type 4, having 28 residues and two disulfide bridges. Examples from the first class are BgK from the sea anemone Bunodosoma granulifera and ShK from the sea "sun" anemone Stichodactyla helianthus.

ShK toxin is a potent blocker of potassium channels. It is a 35-residue peptide originally isolated from sea anemone Stichodactyla helianthus. ShK can block not only $\mathrm{K}_{\mathrm{V}} 1.3$, but also other homologous $\mathrm{K}_{\mathrm{v}}$ subtypes, such as the $\mathrm{K}_{\mathrm{v}} 1.1$, and $\mathrm{K}_{\mathrm{v}} 3.2$ channels [3-5]. Owing to the lack of selectivity, ShK is not suitable for use as a therapeutic agent. Instead, by incorporation of non-natural amino acids or organic labels, analogs of ShK have been designed to be selective for $\mathrm{K}_{\mathrm{v}} 1.3$ over $\mathrm{K}_{\mathrm{v}} 1.1$ and other potassium channels. For example, ShK-Dap22 was generated by replacing its Lys-22 into the positively-charged non-natural residue 1,3-diaminopropionic acid (Dap) [4]. ShK-F6CA was a fluorescein-labeled analog of ShK [6]. Both ShK-186 [3] and ShK-192 [7] were created by attaching the phosphor-Tyr and phosphonic-Phe moieties respectively via a hydrophilic linker to Arg-1. Another ShK analog, ShK-K-amide, was generated by adding a Lys residue and an amide at the C-terminus, and was shown to be a potent and selective blocker of $K_{v} 1.3$ [8]. A recent study by Peng and colleagues [9] demonstrated that ShK-170, which acted as a $\mathrm{K}_{\mathrm{v}} 1.3$ blocker, could protect mice from radiation-induced brain injury. This result suggested that $\mathrm{K}_{\mathrm{v}}$ blockers may have neuroprotective effects.

Changes in the intracellular calcium concentration are coupled with changes in membrane potentials. The changes of membrane potentials are integrated by the activation of calcium-activated $\mathrm{K}^{+}$ channels $\left(\mathrm{K}_{\mathrm{Ca}}\right)$, whose opening probability is increased as a result of membrane hyperpolarization for cytosolic calcium elevation. Many physiological processes, including neurosecretion, smooth muscle tone, action potential shape, and spike frequency adaptation, are regulated by $\mathrm{K}_{\mathrm{Ca}}$ channels activity. The $\mathrm{K}_{\mathrm{Ca}}$ channels can be generally categorized into three subfamilies: BK, SK, and IK channels [10]. Indeed, $\mathrm{K}^{+}$channels play an important role in calcium signaling. Wong $\mathrm{K}$. and collaborators found that the opening of $\mathrm{K}^{+}$channels can be considered as one of the mechanisms responsible for the reduction of intracellular calcium concentration in cultured aortic smooth muscle cells [11]. Jow F. and colleagues proposed a coupling between calcium influx and inactivation of voltage-gated A-type $\mathrm{K}^{+}$channels, resulting in membrane depolarization that contributes to after-hyperpolarization [12]. A number of studies have reported that $\mathrm{Ca}^{2+}$ influx could be regulated by the voltage-gated $\mathrm{K}^{+}$-channel $\mathrm{K}_{\mathrm{v}} 1.3$ and $\mathrm{Ca}^{2+}$-activated $\mathrm{K}^{+}$channel $\mathrm{K}_{\mathrm{Ca}} 3.1$, through the calcium-release activated $\mathrm{Ca}^{2+}$ channel [13-19].

Therefore, taking these facts into consideration, sea anemone ShK peptide highlighted the potential of cnidarians to produce valuable drug candidates. Current genomic, transcriptomic, and proteomic studies provided tools to identify novel peptide families [20]. As a zoantharian, a subclass of Hexacorallia, P. caribaeorum is a sister species of the sea anemone [21]; herein, we studied a peptide precursor, PcShK3, that contains the canonical ShK domain in its structure. Thus, PcShK3 from $P$. caribaeorum expands the number of ShK analogs, and will hopefully provide a valuable variant to serve as a new template to be developed as a therapeutic candidate. From a functional analysis based on experimental evidence, we found that PcShK3 displayed cardio-protective and neuroprotective activity that, in combination with structurally-guided dissection of peptides which restrained the 
structure to the central ShK core, confirms our findings on the elucidation of its intrinsic biological and pharmacological activities.

\section{Results}

\subsection{PcShK3 Is Identified as a Novel ShK-Like Peptide through Molecular Phylogenetic Analysis}

The ShK-like peptide, PcShK3, is structurally similar to other members of the ShK toxin family. It originates from one of our previous studies on the Palythoa caribaeorum transcriptome [22], whose sequence was deposited at DDBJ/EMBL/GenBank under the accession number GESO00000000. In this study, the contig was selected for further computational and biological analysis, including primary sequence analysis, structure modeling, and chemical peptide synthesis for in vivo assays and functional studies using zebrafish larvae. Both the cDNA and amino acid sequences of PcShK3 are shown in Figure 1A.

A

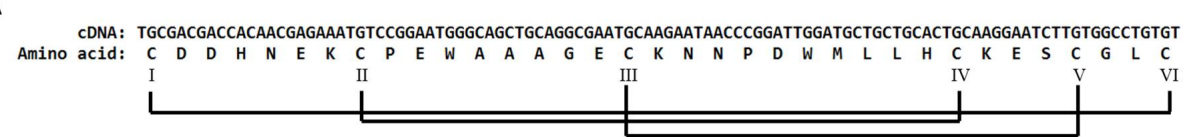

B

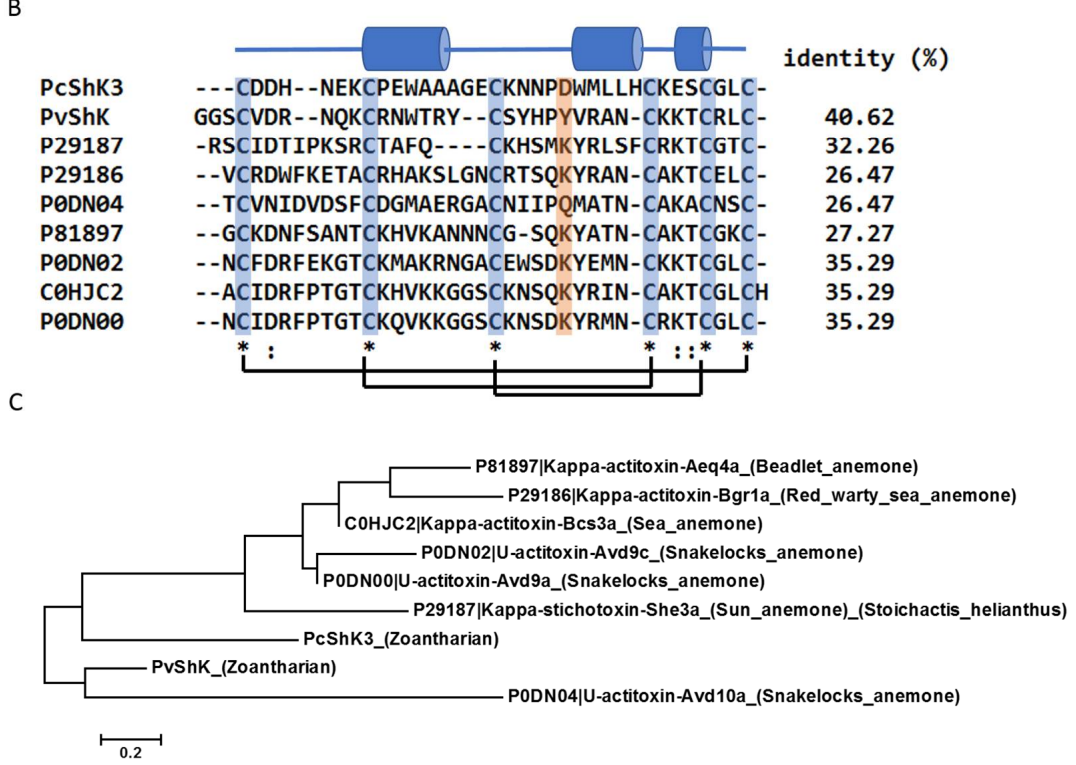

Figure 1. Multiple sequence alignment and phylogenetic analysis of PcShK3 from P. caribaeorum. (A) cDNA and amino sequence of PcShK3; (B) Multiple sequences alignment of $P$. caribaeorum ShK toxin-like peptides and toxins originated from different ShK species of cnidarians (sea anemones). The PcShK3 peptide maintains the cysteine framework, but is distinct in sequence from these sea anemone toxins. Residues highlighted in blue are cysteine. Regions highlighted in orange are residues to block active sites of ion-channels. Cylinders represent $\alpha$-helices; (C) Maximum-likelihood tree from phylogenetic analysis of PcShK3. Notably, except PvShK, the ShK toxin (P29187) originated from Stichodactyla helianthus is most similar to PcShK3.

PcShK3 and its homologs from other species of marine organisms were selected for multiple sequence alignment and phylogenetic analysis. From the Maximum-likelihood tree (Figure 1C), it is seen that PcShK3 clusters well with the ShK toxin of Protopalythoa variabilis, which was predicted from other zoantharian transcriptomes from our previous study [23]. Also, PcShK3 is phylogenetically related to Kappa-stichotoxin-She3a (UniProt ID: P21987). PcShK3 can be grouped with members of the type 1 sea anemone toxins, each of which contains a cysteine framework similar to that of the ShK toxin from the Stichodactyla helianthus sea anemone. They are canonical peptides with 35 to 37 
amino acids, containing six highly conserved cysteine residues. Structures of these peptides are thus stabilized by means of three characteristic disulfide-disulfide bonds, namely, C1-C6, C2-C4, C3-C5. The comparison of PcShK3 with other ShK domain-containing toxins in multiple sequence alignment analysis is shown in Figure 1B. As observed, except for the highly conserved cysteine residues and disulfide-disulfide framework, the amino acid sequences are divergent. Close to the $N$-terminal of PcShK3, two amino acids were deleted, as compared to the ShK sequence.

Based on the crystal structure of ShK, the homology model of PcShK3 was obtained. It is a highly stable structure, as shown in the 10-ns molecular dynamics (MD) simulation of the PcShK3 model at solvent. As shown in Figure 2A, the root-mean-squared deviation (rmsd) of the peptide structure reaches a plateau of $0.15 \AA$ after 3 ns, and only light fluctuations were seen in the terminals. Superpositions of the equilibrated PcShK3 structure to BgK (non-template) and ShK (template) exhibit similar characteristics folds, giving rmsd values of $5.15 \AA$ and $2.42 \AA$, respectively. The first helical segment of PcShK3 highly resembles that of $\mathrm{BgK}$, while the middle, a slightly distorted helix, and the last helical folds, resemble those of ShK (see Figure 2B).
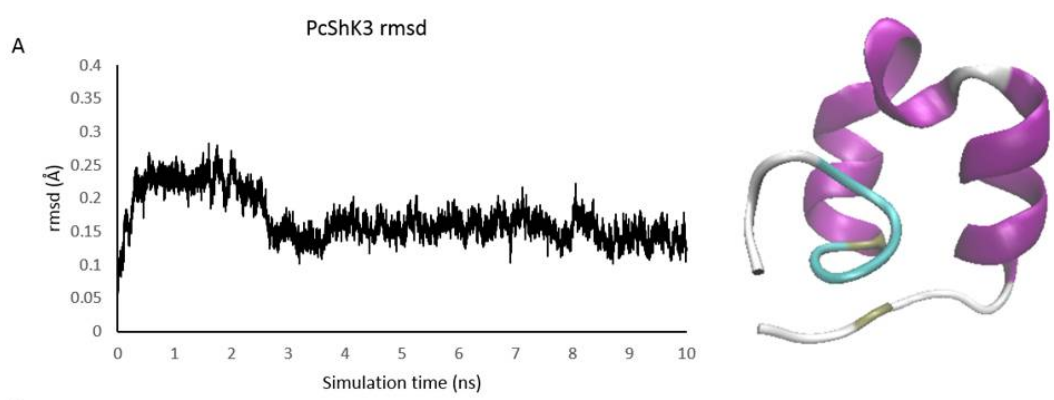

B
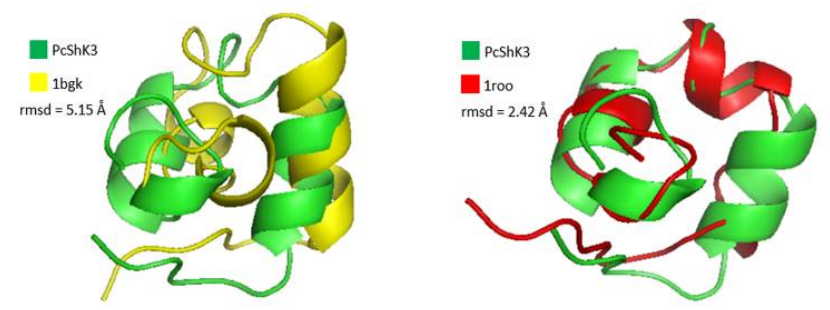

Figure 2. Structure modeling of PcShK3 and structural comparison with ShK and BgK toxins. (A) The homology model of PcShK3 was refined by $10 \mathrm{~ns}$ simulation after minimization and equilibration steps using GROMACS 5.1; (B) Superposition of PcShK3 against crystal structures of ShK toxins, BgK and ShK. The latter was used as template in the homology modeling.

\subsection{PcShK3 Has the Potential to Block to $K_{v} 1.3$ and $K_{C a} 3.1$ through Docking Analysis}

The well-studied ShK peptide is known to block the activities of both $\mathrm{K}_{\mathrm{v}} 1.3$ and $\mathrm{K}_{\mathrm{Ca}} 3.1$ subtypes of voltage-gated $\mathrm{K}^{+}$-ion channels. Electrophysiological studies demonstrated that ShK has a greater affinity for $\mathrm{K}_{\mathrm{v}} 1.3\left(\mathrm{IC}_{50}\right.$ of $\left.133 \mathrm{pM}[6,24]\right)$ than $\mathrm{K}_{\mathrm{Ca}} 3.1$ (IC50 of $\left.30 \mathrm{nM}[5,25]\right)$. Since PcShK3 is phylogenetically related to ShK, it is tempting to speculate that PcShK3 may also block these two channels. MD simulation has confirmed the structural stability of the homology model of PcShK3. To gain further insight into potential interactions between this peptide and the channels, protein-protein docking by the ZDOCK server was performed. ZDOCK [26] is an accurate and widely used tool to solve protein-protein docking problems, also for toxin studies [27-29]. It has a success rate of $70 \%$, and is ranked among the top 10 methods in the CAPRI benchmark test [30]. After docking was complete, the predicted complexes were then fed into PDBe PISA for interfacial residues analysis. As shown in Figure 3A,B, both PcShK3 and ShK interact with the chain D of $\mathrm{K}_{\mathrm{v}} 1.3$ via one hydrogen bond, namely Asn-19 of PcShK3 to the backbone carbonyl oxygen of the channel residue Val- and Tyr-23 of ShK to the backbone carbonyl oxygen of the channel residue Leu-368. Their computed Gibbs 
free energy values are also similar. PcShK3 binding yields $-30.7 \mathrm{kcal} / \mathrm{mol}$, while ShK binding yields $-28.2 \mathrm{kcal} / \mathrm{mol}$. For complexation with $\mathrm{K}_{\mathrm{Ca}} 3.1$, both peptides exploit two residues to interact with the channel, namely Asn-20 and Asp-22, of PcShK3 to the sidechain of the channel residue Trp-262, and Gln-16 and Tyr-23 of ShK to the backbone carbonyl oxygens of the channel residues Ile-251 and Gly-252. The Gibbs free energies of binding in both cases were slightly reduced to $-29.7 \mathrm{kcal} / \mathrm{mol}$ for PcShK3 and $-23.5 \mathrm{kcal} / \mathrm{mol}$ for ShK.

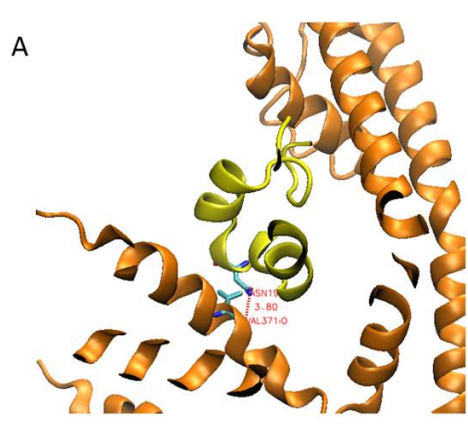

C

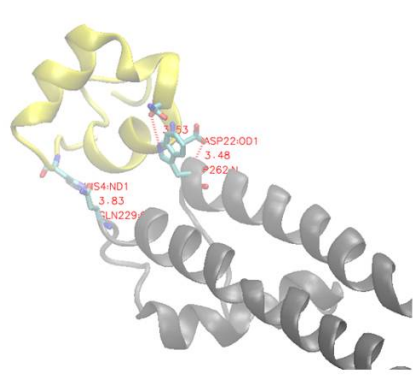

B

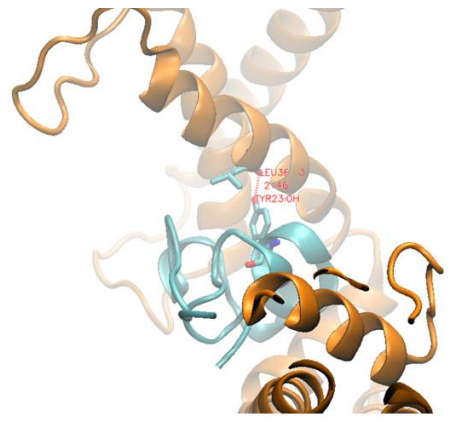

D

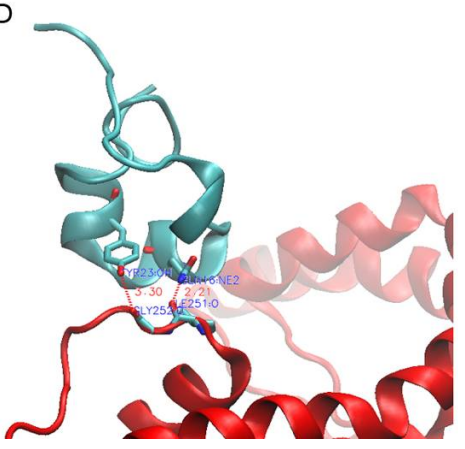

Figure 3. Predicted binding modes of PcShK3 and ShK at the $\mathrm{K}^{+}$-channels. (A) Interface residues between PcShK3 and $K_{v} 1.3$, PcShK3 are shown in yellow; chain D of $K_{v} 1.3$ is shown in orange. The binding sites are shown in gray; (B) Interface residues between ShK and $\mathrm{K}_{\mathrm{v}} 1.3$, ShK are shown in cyan; chain D of $\mathrm{K}_{\mathrm{v}} 1.3$ is shown in orange; (C) Interface residues between PcShK3 and $\mathrm{K}_{\mathrm{Ca}} 3.1$, PcShK3 are shown in yellow; chain $\mathrm{C}$ of $\mathrm{K}_{\mathrm{Ca}} 3.1$ is shown in grey; (D) Interface residues between ShK and $\mathrm{K}_{\mathrm{Ca}} 3.1$, ShK are shown in cyan, and chain $\mathrm{B}$ of $\mathrm{K}_{\mathrm{Ca}} 3.1$ is shown in red.

\subsection{PcShK3 Distributed across Vitelline Membrane and Accumulated in the Yolk Sac Stripe of Zebrafish Larvae}

To evaluate the biodistribution of the PcShK3, rhodamine B-conjugated PcShK3 was also synthesized to track in vivo how PcShK3 was absorbed and distributed in zebrafish.

In Figure 4A, the biodistribution of PcShK3 is shown, and there is an overlap pattern of peptide distribution and EGFP expression in zebrafish. It showed that the peptide translocated across vitelline membrane and was accumulated in the yolk sac stripe. The assessment of PcShK3's biological activity (Figure 4B) demonstrated that zebrafish larvae that were exposed to $40 \mu \mathrm{M}$ of the peptide for $1 \mathrm{~h}$ displayed a mortality rate of about $60 \%$. When the peptide concentration reached $75 \mu \mathrm{M}$ or higher, the lethality was $100 \%$ after 48 h of exposure. Therefore, PcShK3, as ShK-like peptide, did not exhibit a high lethal toxicity to zebrafish larvae, with a $\mathrm{LD}_{50}$ value fitting in the range of 30 to $40 \mu \mathrm{M}$.

\subsection{PcShK3 Hold the Potential to Improve or Restore the Cardiovascular Function at Lower Concentration}

From the docking analysis, we could infer that PcShK3 has the potential to block $\mathrm{K}_{\mathrm{Ca}} 3.1$, a $\mathrm{K}^{+}$-dependent calcium ion channel subtype that is widely distributed in cardiovascular system. Then, $\operatorname{Tg}(C M L C 2: G F P)$ zebrafish were utilized to evaluate the pharmacological activity and the protective effect of PcShK3 act on cardiovascular system. The cardiovascular protective effect of the peptide at concentrations lower than $30 \mu \mathrm{M}$ was evaluated using a set of physiological parameters 
including heart rate, stroke volume (SV), cardiac output (CO), and fractional shortening (\% FS) by means of analyzing the videos and images of the recorded fish hearts. When analyzing the cardiac function parameters of zebrafish larvae exposed to $30 \mu \mathrm{M}$, heart rate, SV, \% FS, and CO were all decreased. However, these parameters increased overall in a dose-dependent manner at concentrations lower than $20 \mu \mathrm{M}$. These findings indicated that our ShK toxin-like peptide derivative, PcShK3, can improve or restore the cardiovascular function at concentrations lower than $20 \mu \mathrm{M}$.
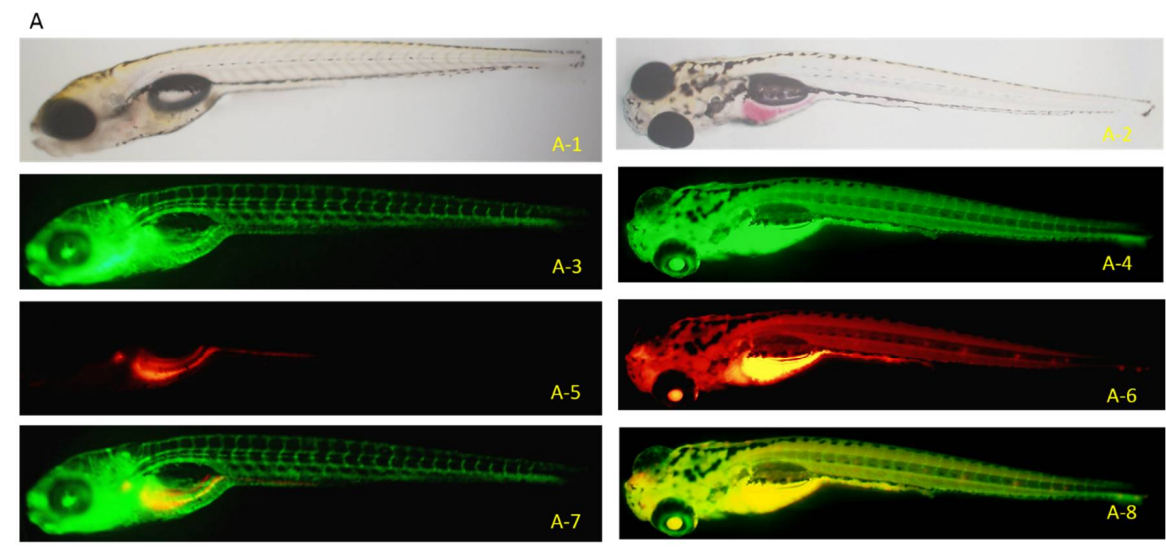

B

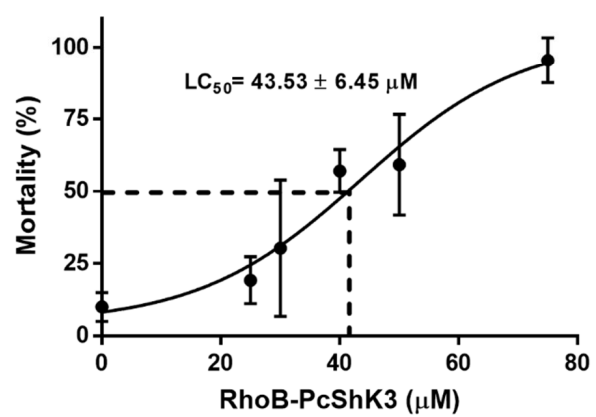

Figure 4. Mortality rate and distribution of P. caribaeorum ShK toxin-like peptide. (A) Fluorescent images of in vivo distribution of rhodamine B-conjugated peptide in $T g(f l i 1: E G F P) y 1$ zebrafish. Bright field pattern of zebrafish (6 dpf) treated with $20 \mu \mathrm{M}$ of RhoB-PcShK3 (A-1) and free rhodamine $\mathrm{B}$ as negative control (A-2) for $24 \mathrm{~h}$. Green fluorescence pattern of EGFP expression in transgenic $\mathrm{Tg}$ (fli1:EGFP)y1 zebrafish (B-3,B-4). Fluorescent images (A-5,A-6) from zebrafish (6 dpf) after incubation with rhodamine B-conjugated PcShK3 $(20 \mu \mathrm{M})$ and free rhodamine B $(20 \mu \mathrm{M})$ for $24 \mathrm{~h}$. Merged images (A-7) of blood vessels (green) and rhodamine B conjugated PcShK3 (red). Merged fluorescent images (A-8) of blood vessels (green) and free rhodamine B (red); (B) Mortality rate of zebrafish larvae after exposure to peptide. The mortality rate reached $50 \%$ when zebrafish larvae was exposed to peptide $(40 \mu \mathrm{M})$ for $8 \mathrm{~h}$. The mortality rate reached $100 \%$ of zebrafish larvae exposed to peptide $(75 \mu \mathrm{M})$ for $48 \mathrm{~h}$. The $\mathrm{LD}_{50}$ is estimated to $43.53 \pm 6.45 \mu \mathrm{M}$.

As seen in Figure 5, the cardiac function parameters were all decreased when zebrafish larvae were exposed to $30 \mu \mathrm{M}$ of the peptide. Cardiac malformation, which included pericardial edema and blood accumulation, occurred at concentrations higher than $30 \mu \mathrm{M}$ (Figure 6A). To zebrafish larvae that survived the peptide, i.e., those that were exposed to $30 \mu \mathrm{M}$ for 4,24 and $48 \mathrm{~h}$, the phenomena of blood accumulation (ba) and pericardial edema (pe) were observed under fluorescence microscope. The phenotypes of cardiac abnormalities induced by a high dosage of the peptide were evident (Figure 6A). The blood accumulation appeared after $4 \mathrm{~h}$ of peptide treatment and decreased after $24 \mathrm{~h}$. The rate of pericardial edema increased from $24 \mathrm{~h}$ post-treatment (hpt) in a dose-dependent manner. The cardiac malformation phenotype and graphical plot are shown in Figure 6B. 

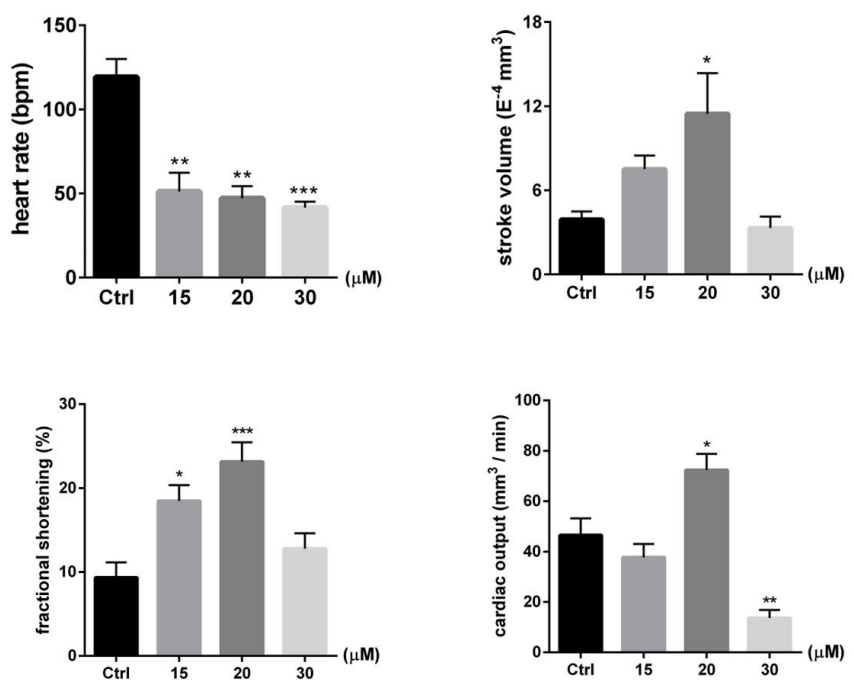

Figure 5. Cardiac functions of zebrafish larvae exposed to various concentrations of PcShK3 peptide for $48 \mathrm{~h}$. Stroke volume (SV), heart rate, cardiac output (CO) and fractional shortening (\% FS) of zebrafish were shown. Data are presented as mean $\pm \operatorname{SEM}(\mathrm{n}=10) .{ }^{*} p<0.05,{ }^{* *} p<0.01,{ }^{* * *} p<0.001$ significantly different compared with the control group.

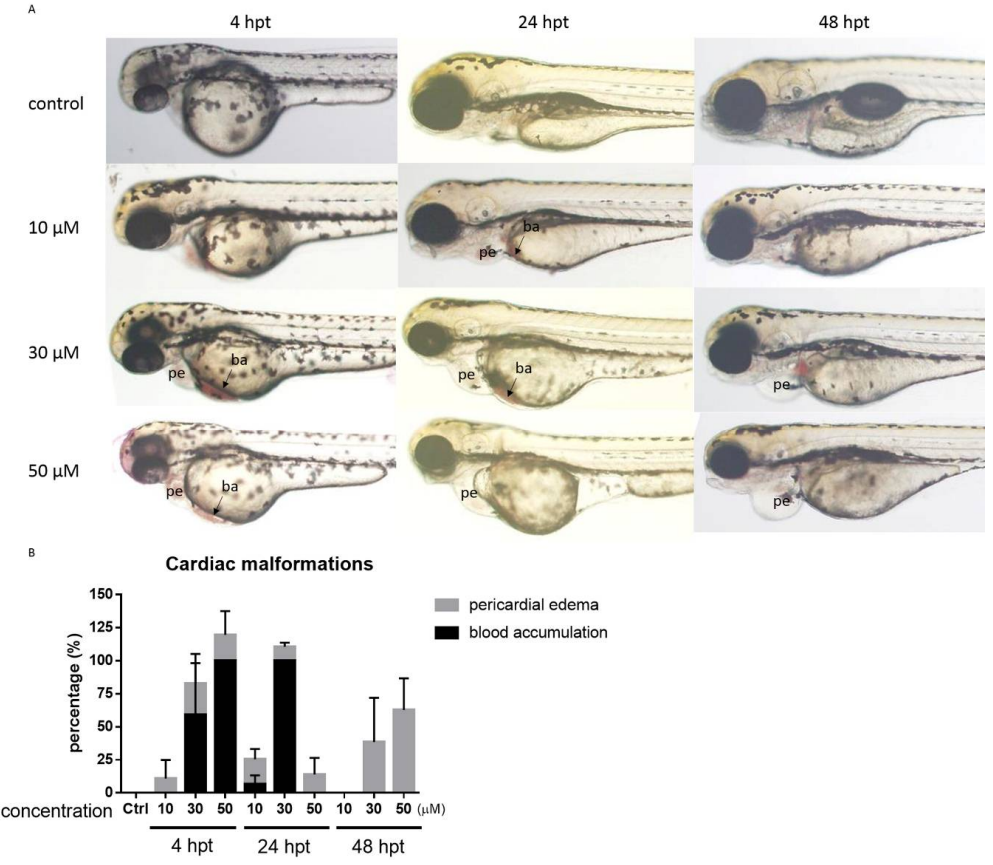

Figure 6. Evaluation of cardiac malformations of zebrafish larvae upon PcShK3 peptide exposure. (A) Time and dose-dependent change in developmental cardiac malformations in larvae after exposure to peptide $(30 \mu \mathrm{M})$ from 4 to $48 \mathrm{hpt}$. The blood accumulation (ba) appeared after $4 \mathrm{~h}$ of drug treatment and decreased after $24 \mathrm{~h}$. The rate of pericardial edema (pe) increased from $24 \mathrm{hpt}$ in a dose-dependent fashion. Values are shown as the mean \pm S.D. of three replicates each with 15 larvae; (B) Phenotype plot of cardiac abnormalities induced by the peptide.

\subsection{PcShK3 Could Prevent the In Vivo Dopaminergic (DA) Neuron Loss Induced by 6-Hydroxydopamine} (6-OHDA) in Zebrafish

To investigate the neuroprotective effect of the peptide, anti-TH whole-mount immunofluorescent staining was used to examine DA neurons in zebrafish larvae. The development of DA neurons in zebrafish is similar to that seen in other vertebrates [31]. As shown in Figure 7, TH-positive neurons 
in diencephalic area were decreased by about $40 \%$ after exposure to 6-OHDA for $48 \mathrm{~h}$ (indicated by yellow brackets in Figure 7A and fluorescence of $\mathrm{TH}^{+}$in Figure 7B). Co-treatment with the peptide was able to attenuate DA neuron loss induced by 6-OHDA when the peptide concentration was $30 \mu \mathrm{M}$. These results suggested that the peptide provides a protective effect against 6-OHDA-induced dopaminergic neuron death in zebrafish larvae.

A
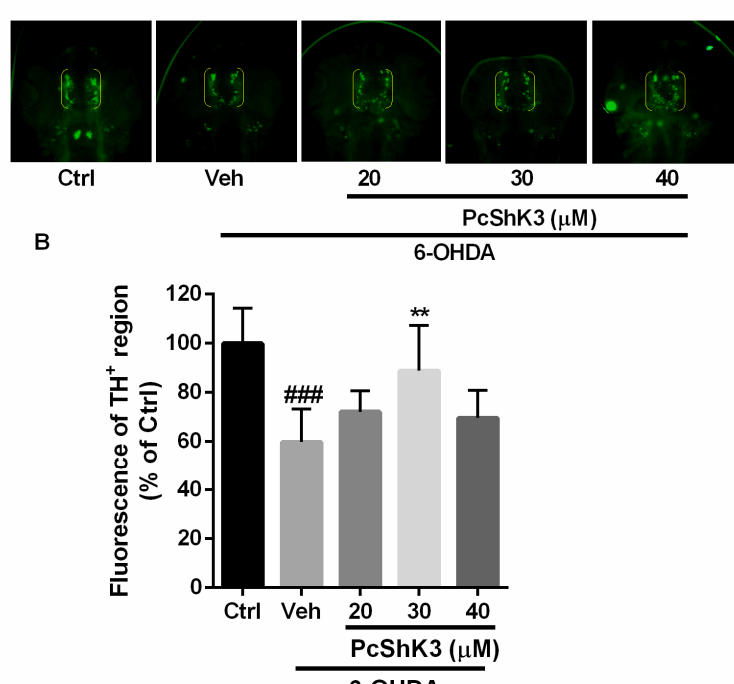

Figure 7. PcShK3 protects against 6-OHDA-induced dopaminergic neuron loss in zebrafish. (A) Representative morphology of DA neurons in zebrafish brain indicated by $\mathrm{TH}$ staining. $\mathrm{TH}^{+}$neurons in diencephalic region are indicated by yellow brackets; (B) quantitative analysis of the area of $\mathrm{TH}^{+}$neurons of each group, \#\# $p<0.001$ versus control group, ${ }^{* *} p<0.01$ versus 6-OHDA group.

In a locomotion test, injury of dopaminergic (DA) neurons by 6-OHDA markedly altered the swimming behavior of zebrafish. As shown in Figure 8,6-OHDA significantly reduced the swimming distance of the larvae after treatment with 6-OHDA. The 6-OHDA-induced lesion was attenuated in a concentration-dependent manner after co-treatment with PcShK3. These data suggested that PcShK3 can suppress 6-OHDA-induced deficits in the locomotive behavior of zebrafish.

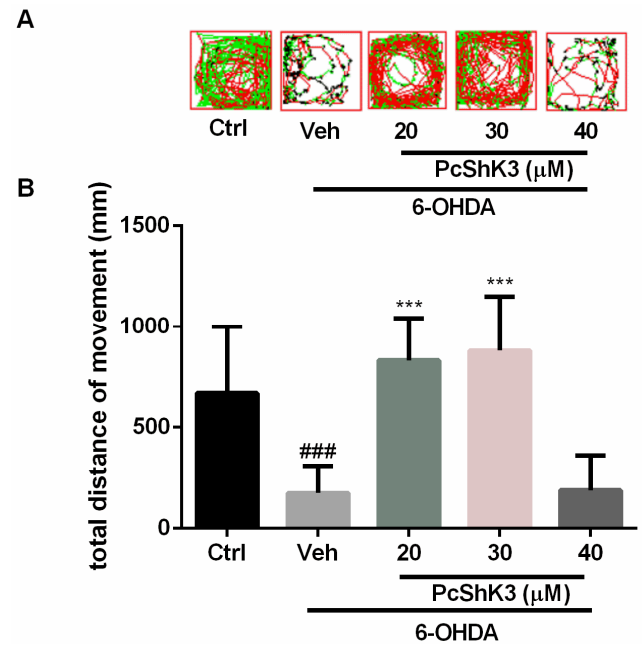

Figure 8. PcShK3 attenuated 6-OHDA-induced lesion in zebrafish. (A) Representative patterns of zebrafish swimming track; (B) Statistics analysis of total distance moved of different treatment groups, eight fish larvae per group from three independent experiments. \#\# $p<0.005$ versus control group, *** $p<0.005$ versus 6-OHDA group. 


\section{Discussions}

In this study, from the P. caribaeorum transcriptome (DDBJ/EMBL/GenBank under the accession GESO00000000), the peptide sequence predicted from the Unigene34015, named PcShK3, was found to have a canonical ShK domain, typical of $\mathrm{K}_{\mathrm{v}} 1$ toxin from sea anemones. From molecular phylogenetic analysis, the homology of PcShK3 was confirmed to share structural similarity with known ShK toxins from many venomous animals, particularly the prototype $\mathrm{ShK}$, and the similar $\mathrm{BgK}$, both originating from distinct species of sea anemone. Moreover, from data of structural modeling and alignments, it was determined that PcShK3 clustered much better with ShK (1roo), rather than with BgK (1 bgk). These sea anemones neurotoxic peptides are known selective inhibitors of $\mathrm{K}^{+}$-channel subtypes. In our docking analysis, the Gibbs free energy of complex of ShK and $\mathrm{K}_{\mathrm{v}} 1.3$ is $-28.2 \mathrm{kcal} / \mathrm{mol}$. This value is indicative that the peptide interacts with $\mathrm{K}_{\mathrm{v}} 1.3$ through hydrogen bonds between Tyr- 23 of ShK and Leu- 368 of $\mathrm{K}_{\mathrm{v}} 1.3$, and the distance was calculated to be $2.46 \AA$. The active site Tyr- 23 in this computational output was near Lys-22, like that observed in other experimental studies [32]. Similarly, from the present data, the ShK toxin-like peptide from P. caribaeorum, PcShK3, could also bind to $K_{v} 1.3$, according to the docking prediction-Asn-19 of PcShK3, part of the binding site, appears to interact to Val-371 of $\mathrm{K}_{\mathrm{v}} 1.3$ through hydrogen bond within $3.80 \AA$ distance, with a Gibbs free energy of $-30.7 \mathrm{kcal} / \mathrm{mol}$. The presence of Lys-22 of ShK was believed to protrude into the channel selectivity filter with Asp-499 of $K_{v} 1.3$ within $6 \AA$ [29,32,33].

Previous studies showed that ShK toxin displays activity similar to that of cholinesterase inhibitors when injected intraperitoneally in mice [34]. Also, ShK could reduce $\mathrm{K}^{+}$currents in neurons from rat dorsal root ganglia [35]. ShK toxin could induce contractile responses in guinea pig ileum [36]. Interestingly, ShK was able to induce anti-obesity activity and reduction of insulin resistance through the blockade to $\mathrm{K}_{\mathrm{v}} 1.3[37,38]$. Interestingly, blockers of $\mathrm{K}_{\mathrm{v}} 1.3$ channel in lymphocytes preferentially inhibit the activation of these cells, and therefore show considerable potential as therapeutics for autoimmune diseases such as multiple sclerosis, type 1 diabetes mellitus, and rheumatoid arthritis [39]. It is worthy of note that most studies on the development of ShK toxin analogs as therapeutic agents focus on targeting $\mathrm{K}_{\mathrm{v}} 1.3$ ion channel in autoimmune processes and diseases.

We have tested the $\mathrm{Tg}(m p o: G F P)$ zebrafish line treated with PcShK3 for immunomodulation response, and found, at a first glance, that PcShK3 was not capable of affecting neutrophil migration (as shown in Figure S1). An important tool for investigating the biodistribution and site of action of a given peptide is the use of fluorescent dyes, which can be covalently linked to the $N$-termini of the peptide sequence. In the survival test, the $\mathrm{LD}_{50}$ of the peptide is $43.53 \pm 6.45 \mu \mathrm{M}$ after $48 \mathrm{~h}$ of exposure, indicating that the toxicity of PcShK3 derivative in zebrafish is relatively low. However, an evident cardiac malformation was observed in zebrafish larvae upon PcShK3 exposure. In contrast, in $24 \mathrm{~h}$ post-treatment (hpt) with the peptide, as seen in Figure 6, blood accumulation and pericardial edema occurred and blood accumulation disappeared at $48 \mathrm{hpt}$. In other investigative studies with the novel zoanthid ShK-like toxin peptide, identified in the Anthozoa Protopalyhtoa variabilis, we have demonstrated a toxic mortality to zebrafish only when peptide concentration was higher than $20 \mu \mathrm{M}$ [23]. Calcium signaling plays a key role in cardiovascular excitability and function. Excitation-contraction (E-C) coupling in the adult mammalian heart is governed by the $\mathrm{Ca}^{2+}$-induced $\mathrm{Ca}^{2+}$ release (CICR) mechanism [40]. Our results showed that survival rate of zebrafish larvae is significantly dependent on calcium levels, indicating that the peptide RhoB-PcShK3 probably interacts with the cardiovascular system through $\mathrm{K}^{+}$-channel blockade, thus modulating the calcium influx. In fact, the PcShK3 homologous ShK toxin from the Stichodactyla sea anemone could also bind to $\mathrm{K}_{\mathrm{Ca}} 3.1$, although the affinity is much less than for other $\mathrm{K}_{\mathrm{v}} 1$ members [3-5,25]. The residues Asn-20 and Asp-22 of PcShK3 were docked into Trp-262 of $\mathrm{K}_{\mathrm{Ca}} 3.1$ chain C, respectively. The Gibbs free energy was found to be $-29.7 \mathrm{kcal} / \mathrm{mol}$. Therefore, PcShK3 could presumably block $\mathrm{K}_{\mathrm{Ca}} 3.1$ in a similar fashion to ShK. 
It is well known that intracellular calcium release from the sarcoplasmic reticulum (SR), through ryanodine receptor, is required for cardiac muscle contraction. The calcium concentration in the cytosol of cardiac myocytes is elevated by approximately 10 -fold from a resting level of $\sim 100 \mathrm{nM}$ to $\sim 1 \mu \mathrm{M}$ with each heart beat [41]. In the cardiomyocyte action potential shape, $\mathrm{K}^{+}$-channels open and cause $\mathrm{K}^{+}$ion outflux during phase 3 [42]. Phase 2 is responsible for the large duration of the action potential, and is important in preventing cardiac arrhythmia [42,43]. Therefore, a defect in the removal of calcium from the cytosol during diastole would impair cardiac relaxation.

Some peptide toxins isolated from the animal venom were found to interact with specific targets, and were then have converted into therapeutics. Successful examples of drugs developed from venom peptides include Captopril ${ }^{\circledR}$, a peptidemimetic which was designed based on pentapeptide toxins from the Brazilian viper and which is now used for hypertension treatment [44]; Byetta ${ }^{\circledR}$, an syncretin peptide from the saliva of Gila monster venom, and used as an anti-diabetic agent to treat type 2 diabetes [45]; and Prialt ${ }^{\circledR}$, derived from the MVIIa omega conotoxin specific to block the subtype $\mathrm{Ca}_{\mathrm{v}} 2.1$ of the calcium ion channel, from the predatory cone snail Conus magus, and used to treat chronic pain $[46,47]$. Despite the high potential for drug development, toxicity is a constant concern regarding to the conversion of venom peptides into drug leads and therapeutics.

Interestingly, our findings demonstrate that the novel ShK-like peptide from P. caribaeorum, potentially has am intrinsic ability to induce cardiovascular protection and neuroprotection, supposedly through $\mathrm{K}^{+}$channels blockade, since calcium signal modulation was also involved. Evaluation of the cardiac function after exposure of zebrafish to the peptide, at a concentration lower than $20 \mu \mathrm{M}$, demonstrated that the heart rate was significantly decreased. Meanwhile, the SV, the \% FS, and the CO were increased almost 100\% compared to the control group. The hypothesis is that, indeed, PcShK3 targets $\mathrm{K}_{\mathrm{v}}$ and $\mathrm{K}_{\mathrm{Ca}}$ channels, and regulates the calcium influx through the membrane of cardiomyocytes, resulting in a specific cardiac protective activity. In addition, some evidence showed that $\mathrm{K}_{\mathrm{v}}$ blockers can exert a neuroprotective effect. It was found that ShK-170, a $\mathrm{K}_{\mathrm{v}} 1.3$ blocker, could in vivo protect against radiation-induced brain injury [9]. Another $\mathrm{K}^{+}$-channel blocker, 4-aminopyridine (4AP), could inhibit neuronal cell death through activation of NMDA receptors after blockade to $\mathrm{K}^{+}$-channel in the murine hippocampus [48]. Furthermore, it was reported that 4AP could decrease MPTP-induced behavioral lesions. [49] reported that 4-aminopyridine decreases MPTP-induced behavioral lesion. In our study, we found that PcShK3 could suppress 6-OHDA-induced deficits in the locomotive behavior of zebrafish, indicating that PcShK3 has a potential ability to induce neuroprotection, an effect that is useful to ameliorate neurodegenerative disorders. This remarkable finding has provided us with insights to develop novel ShK analogs for prospective application in the research and development of an adjuvant therapy to control cardiovascular dysfunctions and neurodegenerative diseases.

In conclusion, the novel ShK-like peptide PcShK3 from P. caribaeorum (a zoantharian species belonging to the subclass Hexacorallia, Cnidaria) has the ability to confer cardiovascular and neurological protective effects in a zebrafish model of drug screening. To further confirm that P. caribaeorum ShK-like peptides act as potent ion-channel blockers of the ShK family of toxins, electrophysiological measurements with subtypes of $\mathrm{K}_{\mathrm{v}} 1$ and $\mathrm{K}_{\mathrm{Ca}}$ channels upon PcShK3 peptide action will be necessary. Moreover, by combining electrophysiology of specific potassium channel subtypes with quantification of intracellular calcium levels, more informative data will give support to hypotheses describing the underlying molecular mechanism of and PcShK3 activity on $\mathrm{K}_{\mathrm{v}} 1$ or $\mathrm{K}_{\mathrm{Ca}}$. Altogether, the present study reported structural and functional data that provide an insightful perspective to characterize novel ShK-like peptide sequences and their derivatives from zoantharians. Particularly, the peptide displayed an interesting cardio-protective and neuroprotective activity that, in combination with structurally-guided dissection of peptides, can be useful for developing peptide-drug candidates for the investigation and prospective adjuvant treatment of cardiovascular and neurodegenerative diseases. 


\section{Materials and Methods}

\subsection{Primary Sequence Analysis, Structure Modeling and Molecular Dynamics Simulation}

The peptide sequences contained ShK domain were downloaded from UniProtKB database. After sequences alignment and editing using the MUSCLE algorithm [50,51], phylogenetic tree was constructed based on the maximum-likelihood method, using the program MEGA version 6 [52]. Reliability of the tree was assessed using 500 bootstrap replicates.

Structures of PcShK3 were modeled using SWISS-MODEL server [53,54], taking the ShK crystal structure as the template [55]. The modeled peptide structure was subjected to energy minimization and molecular dynamics (MD) simulations with CHARMM27 all-atom force field using the GROMACS 5.1 simulation software $[56,57]$. The equilibrated structure was compared to the known structures of ShK (PDB: 1ROO) and BgK (PDB: 1BGK) toxins. Molecular visualization and structure alignment were achieved using the PyMOL program (version 1.8, Schrödinger, LLC, New York, NY, USA, 2015).

\subsection{Molecular Docking Analysis}

The atomic coordinates of the voltage-gated $\mathrm{K}^{+}$-channel subfamily A channels including member 3 (UniProt ID: P22001, $\mathrm{K}_{\mathrm{v}} 1.3$ ), and intermediate conductance $\mathrm{Ca}^{2+}$-activated $\mathrm{K}^{+}$-channel protein 4 (UniProt ID: O15554, $\mathrm{K}_{\mathrm{Ca}} 3$.1) were modeled by homology in the SWISS-MODEL server, taking the $\mathrm{K}_{\mathrm{v}} 1.2$ crystal structure (PDB ID: $2 \mathrm{R} 9 \mathrm{R}$ ) as the template. According to the annotations from UniProt database, ion transport region of $\mathrm{K}_{\mathrm{v}} 1.3$ and $\mathrm{K}_{\mathrm{Ca}} 3.1$ were retained for docking prediction. The Fast Fourier Transform (FFT)-based, initial-stage rigid-body molecular docking algorithm ZDOCK [26] was applied to model the interactions between PcShK3 and the interested channels. PDBe PISA v1.52 [58,59] was utilized for interface residues analysis. The all-structure visualization was achieved using the VMD program v1.9.2 [60].

\subsection{Peptide Synthesis}

Sequences of the PcShK3 peptide were retrieved from the P. caribaeorum transcriptome, and synthesized by solid phase chemistry. The presence of a single peak in analytical reverse-phase HPLC (RP-HPLC) and mass spectrometry (MS) analysis was used to confirm a purity grade over $90 \%$ (Cellmano Biotech Limited, Hefei, China). Complete deprotection and cleavage were carried out with trifluoroacetic acid in water. The crude peptides were precipitated out by the addition of chilled ether. Finally, the crude peptide was purified by HPLC, freeze-dried for storage, and retested by HPLC to make sure that it qualified (Figure S2A). To track the biodistribution of the peptides, a rhodamine B conjugated PcShK3 was synthesized (Figure S2B). The peptides were solubilized in dimethyl sulfoxide (DMSO) to make a $1 \mathrm{mM}$ stock solution, and diluted in an assay buffer (see composition below) when required. Peptide stock solutions were stored in DMSO at $-20{ }^{\circ} \mathrm{C}$.

\subsection{Zebrafish Maintenance}

Transgenic fish lines $\mathrm{Tg}(f l i 1: E G F P) y 1$ and $\mathrm{Tg}(C M L C 2: G F P)$, the wild-type AB strain of zebrafish, were manipulated as described in the Zebrafish Handbook [61]. Briefly, the zebrafish embryos were generated by natural pairwise mating (3-12 months old), and were raised at $28.5^{\circ} \mathrm{C}$ in embryo medium at $28.5^{\circ} \mathrm{C}$. The ethical approval for the animal experiments was granted by the Animal Research Ethics Committee in University of Macau, China.

\subsection{Assessment of Survival Rate and Biodistribution of Peptides in Zebrafish Larvae}

Zebrafish larvae (Tg(fli1:EGFP)y1) at six-day post-fertilization (6-dpf) were exposed to 2-logs (from 5 to $100 \mu \mathrm{M}$ ) of the peptide. The mortality of zebrafish exposed to peptides was determined by observing the presence of heartbeat absence under a light microscope. Zebrafish larvae were separately exposed to a fixed concentration $(20 \mu \mathrm{M})$ of the peptide for $3 \mathrm{~h}$, then collected and mounted 
on microscope glass slides. An IX81 motorized inverted fluorescent microscope (Olympus Co., Tokyo, Japan) was used to monitor the biodistribution of the peptide in zebrafish.

\subsection{Measurement of Morphology and Functions of Zebrafish Heart}

The Cell^R imaging system of an IX71 microscope (Olympus) was utilized to evaluate the morphology of the heart and cardiac functions of $\mathrm{Tg}(C M L C 2: G F P)$ zebrafish after exposure to increasing concentration of peptides $(10 \mu \mathrm{M}, 30 \mu \mathrm{M}$, and $50 \mu \mathrm{M})$ for $4 \mathrm{~h}, 24 \mathrm{~h}$, and $48 \mathrm{~h}$. The zebrafish larvae were placed in $1 \%$ agarose to fix in a dorsal orientation. A video segment of each larva was recorded for $10 \mathrm{~s}$ (13-15 frames per second) for heart morphology examination. The parameters and morphology of ventricular function of zebrafish were measured, as previously described [62,63]. Briefly, the formula $\mathrm{V}=4 / 3 \pi \mathrm{ab}^{2}$ was used to calculate the volume of ventricles. The longitudinal axis was represented by "a", while the lateral axis was represented by "b". Stroke volume (SV) was calculated by end-diastolic volume (EDV) and end-systolic volume (ESV). Cardiac output (CO) was determined by heart rate $\times$ stroke volume. Percentage of fractional shortening $(\% \mathrm{FS})$ was calculated by the formula $\mathrm{FS} \%=($ diastolic diameter - dystolic diameter $) /$ dystolic diameter $\times 100 \%$.

\subsection{Anti-Tyrosine Hydroxylase (TH) Whole-Mount Immunostaining}

Anti-tyrosine hydroxylase (TH) whole-mount immunostaining of zebrafish was carried out as previously described [64,65]. Briefly, zebrafish embryos at $1 \mathrm{dpf}$ were exposed to $250 \mu \mathrm{M}$ 6-hydroxydopamine (6-OHDA) with or without the peptides for 2 days. Then the larvae were fixed with $4 \%$ paraformaldehyde in PBS for $30 \mathrm{~min}$, rinsed, and stored at $-20^{\circ} \mathrm{C}$ in absolute methanol. Semi-quantification of $\mathrm{TH}^{+}$cells was assessed by an investigator blinded to the drug treatment history of zebrafish, using ImageJ software [66]. Results were expressed as percentage of area of $\mathrm{TH}^{+}$cells in control group.

\subsection{Locomotion Behavioral Test}

The locomotion test was carried out as described in previous studies [64,65]. Briefly, AB strain zebrafish larvae at $3 \mathrm{dpf}$ were under co-treatment of $250 \mu \mathrm{M}$ 6-OHDA with various concentrations of the peptides for 4 days; then, zebrafish at $7 \mathrm{dpf}$ were transferred into 96-well plates (1 fish/well). The 96-well plates were put into a Zebrabox and the swimming behavior was monitored by an automated video tracking system (Viewpoint, ZebraLab, LifeSciences, Lyon, France). Before the start of data acquisition, the larvae were settled to allow them to accommodate themselves to the environment in the Zebrabox. The swimming pattern of each fish was recorded in five sessions of $10 \mathrm{~min}$ each. The total distance traveled was recorded as the distance that a given zebrafish larva was capable of swimming during the $10 \mathrm{~min}$ long session. A statistical analysis of the total distance traveled by each zebrafish larva in the different treatment groups was performed using the ANOVA and Dunnett's test.

Supplementary Materials: The following are available online at http:/ /www.mdpi.com/2072-6651/10/6/238/s1. Figure S1: Immunomodulation response assessment of $T g(m p o: G F P)$ zebrafish larvae after PcShK3 treatment, Figure S2: Purification and characterization of the peptides.

Author Contributions: Q.L. designed the research, performed computational work, analyzed data, and wrote the paper; G.G. designed the research, performed zebrafish experiment, and analyzed data; S.W.I.S. performed computational work; H.Y., C.T.T.W. and Y.C.T. analyzed data; G.R.-B. and S.M.-Y.L. designed the research and wrote the paper.

Funding: Research at University of Macau was supported by grants from the Science and Technology Development Fund (FDCT) of Macao SAR (Ref. No. 069/2015/A2 and No. 134/2014/A3), Research Committee, University of Macau (MYRG2016-00133-ICMS-QRCM, MYRG2015-00182-ICMS-QRCM, and MYRG2016-00129-ICMS-QRCM), and Shenzhen City Science \& Technology Innovation Program (CYZZ20160525094052606). At Federal University of CE, research was financially supported by the Brazilian National Council for Scientific and Technological Development, CNPq (Marine Biotechnology Network_Proc. 408835/2013-3), the Ministry of Science, Technology and Innovation (MCTI), Brasília, DF, Brazil. 
Acknowledgments: This work was performed in part at the high-performance computing cluster (HPCC) which is supported by Information and Communication Technology Office (ICTO) of the University of Macau.

Conflicts of Interest: The authors declare no conflict of interest.

\section{References}

1. Jouiaei, M.; Sunagar, K.; Federman Gross, A.; Scheib, H.; Alewood, P.F.; Moran, Y.; Fry, B.G. Evolution of an ancient venom: Recognition of a novel family of cnidarian toxins and the common evolutionary origin of sodium and potassium neurotoxins in sea anemone. Mol. Biol. Evol. 2015, 32, 1598-1610. [CrossRef] [PubMed]

2. King, G. Venoms to Drugs: Venom as a Source for the Development of Human Therapeutics; Royal Society of Chemistry: London, UK, 2015.

3. Beeton, C.; Pennington, M.W.; Wulff, H.; Singh, S.; Nugent, D.; Crossley, G.; Khaytin, I.; Calabresi, P.A.; Chen, C.Y.; Gutman, G.A.; et al. Targeting effector memory T cells with a selective peptide inhibitor of $\mathrm{K}_{\mathrm{v}} 1.3$ channels for therapy of autoimmune diseases. Mol. Pharmacol. 2005, 67, 1369-1381. [CrossRef] [PubMed]

4. Kalman, K.; Pennington, M.W.; Lanigan, M.D.; Nguyen, A.; Rauer, H.; Mahnir, V.; Paschetto, K.; Kem, W.R.; Grissmer, S.; Gutman, G.A. ShK-Dap22, a potent $\mathrm{K}_{\mathrm{v}} 1$.3-specific immunosuppressive polypeptide. J. Biol. Chem. 1998, 273, 32697-32707. [CrossRef] [PubMed]

5. Yan, L.; Herrington, J.; Goldberg, E.; Dulski, P.M.; Bugianesi, R.M.; Slaughter, R.S.; Banerjee, P.; Brochu, R.M.; Priest, B.T.; Kaczorowski, G.J.; et al. Stichodactyla helianthus peptide, a pharmacological tool for studying $\mathrm{K}_{\mathrm{v}} 3.2$ channels. Mol. Pharmacol. 2005, 67, 1513-1521. [CrossRef] [PubMed]

6. Beeton, C.; Wulff, H.; Singh, S.; Botsko, S.; Crossley, G.; Gutman, G.A.; Cahalan, M.D.; Pennington, M.; Chandy, K.G. A novel fluorescent toxin to detect and investigate $\mathrm{K}_{\mathrm{v}} 1.3$ channel up-regulation in chronically activated T lymphocytes. J. Biol. Chem. 2003, 278, 9928-9937. [CrossRef] [PubMed]

7. Pennington, M.W.; Beeton, C.; Galea, C.A.; Smith, B.J.; Chi, V.; Monaghan, K.P.; Garcia, A.; Rangaraju, S.; Giuffrida, A.; Plank, D.; et al. Engineering a stable and selective peptide blocker of the $\mathrm{K}_{\mathrm{v}} 1.3$ channel in T lymphocytes. Mol. Pharmacol. 2009, 75, 762-773. [CrossRef] [PubMed]

8. Pennington, M.W.; Harunur Rashid, M.; Tajhya, R.B.; Beeton, C.; Kuyucak, S.; Norton, R.S. AC-terminally amidated analogue of $\mathrm{ShK}$ is a potent and selective blocker of the voltage-gated potassium channel $\mathrm{K}_{\mathrm{v}} 1.3$. FEBS Lett. 2012, 586, 3996-4001. [CrossRef] [PubMed]

9. Peng, Y.; Lu, K.; Li, Z.; Zhao, Y.; Wang, Y.; Hu, B.; Xu, P.; Shi, X.; Zhou, B.; Pennington, M.; et al. Blockade of $\mathrm{K}_{\mathrm{v}} 1.3$ channels ameliorates radiation-induced brain injury. Neuro Oncol. 2014, 16, 528-539. [CrossRef] [PubMed]

10. Vergara, C.; Latorre, R.; Marrion, N.V.; Adelman, J.P. Calcium-activated potassium channels. Curr. Opin. Neurobiol. 1998, 8, 321-329. [CrossRef]

11. Wong, K.L.; Yang, H.Y.; Chan, P.; Cheng, T.H.; Liu, J.C.; Hsu, F.L.; Liu, I.M.; Cheng, Y.W.; Cheng, J.T. Isosteviol as a potassium channel opener to lower intracellular calcium concentrations in cultured aortic smooth muscle cells. Planta Med. 2004, 70, 108-112. [PubMed]

12. Jow, F.; Zhang, Z.H.; Kopsco, D.C.; Carroll, K.C.; Wang, K. Functional coupling of intracellular calcium and inactivation of voltage-gated $\mathrm{K}_{\mathrm{v}} 1.1 / \mathrm{K}_{\mathrm{v}}$ beta1.1 A-type $\mathrm{K}^{+}$channels. Proc. Natl. Acad. Sci. USA 2004, 101, 15535-15540. [CrossRef] [PubMed]

13. Feske, S.; Gwack, Y.; Prakriya, M.; Srikanth, S.; Puppel, S.H.; Tanasa, B.; Hogan, P.G.; Lewis, R.S.; Daly, M.; Rao, A. A mutation in Orai1 causes immune deficiency by abrogating CRAC channel function. Nature 2006, 441, 179-185. [CrossRef] [PubMed]

14. Feske, S.; Prakriya, M.; Rao, A.; Lewis, R.S. A severe defect in CRAC Ca ${ }^{2+}$ channel activation and altered $\mathrm{K}^{+}$channel gating in T cells from immunodeficient patients. J. Exp. Med. 2005, 202, 651-662. [CrossRef] [PubMed]

15. Zhang, S.L.; Yu, Y.; Roos, J.; Kozak, J.A.; Deerinck, T.J.; Ellisman, M.H.; Stauderman, K.A.; Cahalan, M.D. STIM1 is a $\mathrm{Ca}^{2+}$ sensor that activates CRAC channels and migrates from the $\mathrm{Ca}^{2+}$ store to the plasma membrane. Nature 2005, 437, 902-905. [CrossRef] [PubMed]

16. Prakriya, M.; Feske, S.; Gwack, Y.; Srikanth, S.; Rao, A.; Hogan, P.G. Orai1 is an essential pore subunit of the CRAC channel. Nature 2006, 443, 230-233. [CrossRef] [PubMed] 
17. Vig, M.; Peinelt, C.; Beck, A.; Koomoa, D.L.; Rabah, D.; Koblan-Huberson, M.; Kraft, S.; Turner, H.; Fleig, A.; Penner, R.; et al. CRACM1 is a plasma membrane protein essential for store-operated $\mathrm{Ca}^{2+}$ entry. Science 2006, 312, 1220-1223. [CrossRef] [PubMed]

18. Yeromin, A.V.; Zhang, S.L.; Jiang, W.; Yu, Y.; Safrina, O.; Cahalan, M.D. Molecular identification of the CRAC channel by altered ion selectivity in a mutant of Orai. Nature 2006, 443, 226-229. [CrossRef] [PubMed]

19. Lis, A.; Peinelt, C.; Beck, A.; Parvez, S.; Monteilh-Zoller, M.; Fleig, A.; Penner, R. CRACM1, CRACM2, and CRACM3 are store-operated $\mathrm{Ca}^{2+}$ channels with distinct functional properties. Curr. Biol. 2007, 17, 794-800. [CrossRef] [PubMed]

20. Prentis, P.J.; Pavasovic, A.; Norton, R.S. Sea Anemones: Quiet Achievers in the Field of Peptide Toxins. Toxins (Basel) 2018, 10, 36. [CrossRef] [PubMed]

21. Kayal, E.; Bastian, B.; Pankey, M.S.; Ohdera, A.; Medina, M.; Plachetzki, D.C.; Collins, A.; Ryan, J.F. Comprehensive phylogenomic analyses resolve cnidarian relationships and the origins of key organismal traits. PeerJ Preprints 2017, 5. [CrossRef]

22. Liao, Q.; Li, S.; Siu, S.W.I.; Yang, B.; Huang, C.; Chan, J.Y.-W.; Morlighem, J.-É.; Wong, C.T.T.; Rádis-Baptista, G.; Lee, S.M.-Y. Novel Kunitz-like peptides discovered in the zoanthid Palythoa caribaeorum through transcriptome sequencing. J. Proteome Res. 2018, 17, 891-902. [CrossRef] [PubMed]

23. Huang, C.; Morlighem, J.-É.R.; Zhou, H.; Lima, É.P.; Gomes, P.B.; Cai, J.; Lou, I.; Pérez, C.D.; Lee, S.M.; Rádis-Baptista, G. The Transcriptome of the Zoanthid Protopalythoa variabilis (Cnidaria, Anthozoa) Predicts a Basal Repertoire of Toxin-like and Venom-Auxiliary Polypeptides. Genome Biol. Evol. 2016, 8, 3045-3064. [CrossRef] [PubMed]

24. Pennington, M.W.; Byrnes, M.E.; Zaydenberg, I.; Khaytin, I.; de Chastonay, J.; Krafte, D.S.; Hill, R.; Mahnir, V.M.; Volberg, W.A.; Gorczyca, W.; et al. Chemical synthesis and characterization of ShK toxin: A potent potassium channel inhibitor from a sea anemone. Int. J. Pept. Protein Res. 1995, 46, 354-358. [CrossRef] [PubMed]

25. Rauer, H.; Pennington, M.; Cahalan, M.; Chandy, K.G. Structural conservation of the pores of calcium-activated and voltage-gated potassium channels determined by a sea anemone toxin. J. Biol. Chem. 1999, 274, 21885-21892. [CrossRef] [PubMed]

26. Pierce, B.G.; Hourai, Y.; Weng, Z. Accelerating protein docking in ZDOCK using an advanced 3D convolution library. PLoS ONE 2011, 6, e24657. [CrossRef] [PubMed]

27. Chen, R.; Chung, S.H. Engineering a potent and specific blocker of voltage-gated potassium channel $\mathrm{K}_{\mathrm{v}} 1.3$, a target for autoimmune diseases. Biochemistry 2012, 51, 1976-1982. [CrossRef] [PubMed]

28. Chen, R.; Chung, S.H. Molecular dynamics simulations of scorpion toxin recognition by the $\mathrm{Ca}^{2+}$-activated potassium channel $\mathrm{K}_{\mathrm{Ca}} 3.1$. Biophys. J. 2013, 105, 1829-1837. [CrossRef] [PubMed]

29. Chen, R.; Robinson, A.; Gordon, D.; Chung, S.H. Modeling the binding of three toxins to the voltage-gated potassium channel $\left(\mathrm{K}_{\mathrm{v}} 1.3\right)$. Biophys. J. 2011, 101, 2652-2660. [CrossRef] [PubMed]

30. Chen, R.; Tong, W.; Mintseris, J.; Li, L.; Weng, Z. ZDOCK predictions for the CAPRI challenge. Proteins 2003, 52, 68-73. [CrossRef] [PubMed]

31. Rink, E.; Wullimann, M.F. The teleostean (zebrafish) dopaminergic system ascending to the subpallium (striatum) is located in the basal diencephalon (posterior tuberculum). Brain Res. 2001, 889, 316-330. [CrossRef]

32. Lanigan, M.D.; Kalman, K.; Lefievre, Y.; Pennington, M.W.; Chandy, K.G.; Norton, R.S. Mutating a critical lysine in ShK toxin alters its binding configuration in the pore-vestibule region of the voltage-gated potassium channel, $\mathrm{K}_{v}$ 1.3. Biochemistry 2002, 41, 11963-11971. [CrossRef] [PubMed]

33. Lange, A.; Giller, K.; Hornig, S.; Martin-Eauclaire, M.F.; Pongs, O.; Becker, S.; Baldus, M. Toxin-induced conformational changes in a potassium channel revealed by solid-state NMR. Nature 2006, 440, 959-962. [CrossRef] [PubMed]

34. Chi, V.; Pennington, M.W.; Norton, R.S.; Tarcha, E.J.; Londono, L.M.; Sims-Fahey, B.; Upadhyay, S.K.; Lakey, J.T.; Iadonato, S.; Wulff, H.; et al. Development of a sea anemone toxin as an immunomodulator for therapy of autoimmune diseases. Toxicon 2012, 59, 529-546. [CrossRef] [PubMed]

35. Beeton, C.; Pennington, M.W.; Norton, R.S. Analogs of the sea anemone potassium channel blocker ShK for the treatment of autoimmune diseases. Inflamm. Allergy Drug Targets 2011, 10, 313-321. [CrossRef] [PubMed] 
36. Suarez-Kurtz, G.; Vianna-Jorge, R.; Pereira, B.F.; Garcia, M.L.; Kaczorowski, G.J. Peptidyl inhibitors of shaker-type $\mathrm{K}_{\mathrm{v}} 1$ channels elicit twitches in guinea pig ileum by blocking $\mathrm{K}_{\mathrm{v}} 1.1$ at enteric nervous system and enhancing acetylcholine release. J. Pharmacol. Exp. Ther. 1999, 289, 1517-1522. [PubMed]

37. Tucker, K.; Overton, J.M.; Fadool, D.A. $\mathrm{K}_{\mathrm{v}} 1.3$ gene-targeted deletion alters longevity and reduces adiposity by increasing locomotion and metabolism in melanocortin-4 receptor-null mice. Int. J. Obes. (Lond.) 2008, 32, 1222-1232. [CrossRef] [PubMed]

38. Xu, J.; Koni, P.A.; Wang, P.; Li, G.; Kaczmarek, L.; Wu, Y.; Li, Y.; Flavell, R.A.; Desir, G.V. The voltage-gated potassium channel $\mathrm{K}_{\mathrm{V}} 1.3$ regulates energy homeostasis and body weight. Hum. Mol. Genet. 2003, 12, 551-559. [CrossRef] [PubMed]

39. Norton, R.S.; Pennington, M.W.; Beeton, C. Case study 2: Transforming a toxin into a therapeutic: The sea anemone potassium channel blocker ShK toxin for treatment of autoimmune diseases. In Venoms to Drugs; IMB: Wollongong, Austraia, 2015; pp. 255-274.

40. Zhang, G.Q.; Wei, H.; Lu, J.; Wong, P.; Shim, W. Identification and characterization of calcium sparks in cardiomyocytes derived from human induced pluripotent stem cells. PLoS ONE 2013, 8, e55266.

41. Marks, A.R. Calcium and the heart: A question of life and death. J. Clin. Investig. 2003, 111, 597-600. [CrossRef] [PubMed]

42. Morad, M.; Tung, L. Ionic events responsible for the cardiac resting and action potential. Am. J. Cardiol. 1982, 49, 584-594. [CrossRef]

43. Tse, G. Mechanisms of cardiac arrhythmias. J. Arrhythm. 2016, 32, 75-81. [CrossRef] [PubMed]

44. Koh, C.Y.; Kini, R.M. From snake venom toxins to therapeutics-Cardiovascular examples. Toxicon 2012, 59, 497-506. [CrossRef] [PubMed]

45. Furman, B.L. The development of Byetta (exenatide) from the venom of the Gila monster as an anti-diabetic agent. Toxicon 2012, 59, 464-471. [CrossRef] [PubMed]

46. Miljanich, G.P. Ziconotide: Neuronal calcium channel blocker for treating severe chronic pain. Curr. Med. Chem. 2004, 11, 3029-3040. [CrossRef] [PubMed]

47. Schmidtko, A.; Lotsch, J.; Freynhagen, R.; Geisslinger, G. Ziconotide for treatment of severe chronic pain. Lancet 2010, 375, 1569-1577. [CrossRef]

48. Ogita, K.; Okuda, H.; Watanabe, M.; Nagashima, R.; Sugiyama, C.; Yoneda, Y. In vivo treatment with the $\mathrm{K}^{+}$ channel blocker 4-aminopyridine protects against kainate-induced neuronal cell death through activation of NMDA receptors in murine hippocampus. Neuropharmacology 2005, 48, 810-821. [CrossRef] [PubMed]

49. Taherian, R.; Ahmadi, M.A. 4-aminopyridine decreases MPTP-induced behavioral disturbances in animal model of Parkinson's disease. Int. Clin. Neurosci. J. 2016, 2, 142-146.

50. Edgar, R.C. MUSCLE: Multiple sequence alignment with high accuracy and high throughput. Nucleic Acids Res. 2004, 32, 1792-1797. [CrossRef] [PubMed]

51. Edgar, R.C. MUSCLE: A multiple sequence alignment method with reduced time and space complexity. BMC Bioinform. 2004, 5, 113. [CrossRef] [PubMed]

52. Tamura, K.; Stecher, G.; Peterson, D.; Filipski, A.; Kumar, S. MEGA6: Molecular Evolutionary Genetics Analysis version 6.0. Mol. Biol. Evol. 2013, 30, 2725-2729. [CrossRef] [PubMed]

53. Biasini, M.; Bienert, S.; Waterhouse, A.; Arnold, K.; Studer, G.; Schmidt, T.; Kiefer, F.; Gallo Cassarino, T.; Bertoni, M.; Bordoli, L.; et al. SWISS-MODEL: Modelling protein tertiary and quaternary structure using evolutionary information. Nucleic Acids Res. 2014, 42, W252-W258. [CrossRef] [PubMed]

54. Kopp, J.; Schwede, T. The SWISS-MODEL Repository: New features and functionalities. Nucleic Acids Res. 2006, 34, D315-D318. [CrossRef] [PubMed]

55. Tudor, J.E.; Pallaghy, P.K.; Pennington, M.W.; Norton, R.S. Solution structure of ShK toxin, a novel potassium channel inhibitor from a sea anemone. Nat. Struct. Biol. 1996, 3, 317-320. [CrossRef] [PubMed]

56. Pronk, S.; Pall, S.; Schulz, R.; Larsson, P.; Bjelkmar, P.; Apostolov, R.; Shirts, M.R.; Smith, J.C.; Kasson, P.M.; van der Spoel, D.; et al. GROMACS 4.5: A high-throughput and highly parallel open source molecular simulation toolkit. Bioinformatics 2013, 29, 845-854. [CrossRef] [PubMed]

57. Van Der Spoel, D.; Lindahl, E.; Hess, B.; Groenhof, G.; Mark, A.E.; Berendsen, H.J. GROMACS: Fast, flexible, and free. J. Comput. Chem. 2005, 26, 1701-1718. [CrossRef] [PubMed]

58. Krissinel, E. Crystal contacts as nature's docking solutions. J. Comput. Chem. 2010, 31, 133-143. [CrossRef] [PubMed] 
59. Krissinel, E.; Henrick, K. Inference of macromolecular assemblies from crystalline state. J. Mol. Biol. 2007, 372, 774-797. [CrossRef] [PubMed]

60. Humphrey, W.; Dalke, A.; Schulten, K. VMD: Visual molecular dynamics. J. Mol. Graph. 1996, 14, 33-38. [CrossRef]

61. Westerfield, M. A Guide for the Laboratory Use of Zebrafish (Danio rerio) Eugene, 4th ed.; University of Oregon Press: Eugene, OR, USA, 2000; pp. 1.1, 9.7, 10.16.

62. Chan, J.Y.; Zhou, H.; Kwan, Y.W.; Chan, S.W.; Radis-Baptista, G.; Lee, S.M. Evaluation in zebrafish model of the toxicity of rhodamine B-conjugated crotamine, a peptide potentially useful for diagnostics and therapeutics. J. Biochem. Mol. Toxicol. 2017, 31. [CrossRef] [PubMed]

63. Wang, L.; Zhang, X.; Chan, J.Y.; Shan, L.; Cui, G.; Cui, Q.; Wang, Y.; Li, J.; Chen, H.; Zhang, Q.; et al. A Novel Danshensu Derivative Prevents Cardiac Dysfunction and Improves the Chemotherapeutic Efficacy of Doxorubicin in Breast Cancer Cells. J. Cell. Biochem. 2016, 117, 94-105. [CrossRef] [PubMed]

64. Zhang, L.Q.; Sa, F.; Chong, C.M.; Wang, Y.; Zhou, Z.Y.; Chang, R.C.; Chan, S.W.; Hoi, P.M.; Yuen Lee, S.M. Schisantherin A protects against 6-OHDA-induced dopaminergic neuron damage in zebrafish and cytotoxicity in SH-SY5Y cells through the ROS/NO and AKT/GSK3beta pathways. J. Ethnopharmacol. 2015, 170, 8-15. [CrossRef] [PubMed]

65. Zhang, Z.J.; Cheang, L.C.; Wang, M.W.; Li, G.H.; Chu, I.K.; Lin, Z.X.; Lee, S.M. Ethanolic extract of fructus Alpinia oxyphylla protects against 6-hydroxydopamine-induced damage of PC12 cells in vitro and dopaminergic neurons in zebrafish. Cell. Mol. Neurobiol. 2012, 32, 27-40. [CrossRef] [PubMed]

66. Schneider, C.A.; Rasband, W.S.; Eliceiri, K.W. NIH Image to ImageJ: 25 years of image analysis. Nat. Methods 2012, 9, 671-675. [CrossRef] [PubMed]

(C) 2018 by the authors. Licensee MDPI, Basel, Switzerland. This article is an open access article distributed under the terms and conditions of the Creative Commons Attribution (CC BY) license (http:/ / creativecommons.org/licenses/by/4.0/). 